\title{
Adult Learning and the Advantages of the Online Learning Experience
}

Stephanie Hoon, Faculty

stephaniehoon@westcliff.edu

Penny Wilkins, External contributor

drpwilkins@att.net

Angela Perry, External contributor

\begin{abstract}
This paper discusses several benefits of the online educational experience, specifically as it pertains to the adult learner. The paper focuses on the aspects of collaboration, flexibility, and cultural opportunities. The work concludes that online education is ideal for adult learners because of the aspects of collaboration, flexibility, and diversity it provides utilizing the constructivist approach.
\end{abstract}




\section{INTRODUCTION}

Although criticized by some, online education offers several advantages in today's world. In fact, online education is a preferred method of many students, including the adult learner. In some cases, this type of learning can prove to be even more beneficial than more traditional methods (Luscinski, 2017). Online education has been studied now for many years. White and Weight (2000) point out that there is a connection between online education and the dynamics of human communication. As such, it offers advantages beyond those associated with technological forms of correspondence courses and interactive television programs, which were some of the beginning forms of non-classroom education. Adult learners, looking for an education, seem especially likely to thrive in the online environment because they require specific elements in order to benefit from the education process. For instance, adult learners may be more attracted to courses that permit freedom with respect to their daily schedules, especially when considering family and careers.

\section{Adult learners as Collaborative Partners}

Adult learners introduce a different dynamic to learning in that they bring a wealth of knowledge to the classroom that can enrich the course content (White \& Weight, 2000). Both personal and professional experiences add to an adult learner's ability to see things from different perspectives, as well as create alternative solutions and implement critical thinking approaches to solve problems. However, factors such as ineffective planning skills and poor time management can contribute to failure in an online program (Wright, 2015). However, some factors align very well with online programs. As Rudestam and Schoenholtz-Read (2002) described, work experience and prior knowledge play important roles in the learning experiences of adults. Additionally, Wright (2015) found that offering a pre-orientation workshop helped to contribute to adult online learners' success. Online learning is reinforced with everimproving technology that lends to a collaborative learning environment. Also, an online environment may exceed that of the traditional classroom to the extent that it is a round the clock environment, permitting students to connect to the learning process at any time (Hiltz, 1997).

Additionally, the passiveness of the traditional educational process (e.g., lecture presentations) does not serve to capitalize on the knowledge of the adult learner, nor does it offer other elements adults prefer. For instance, adult learners may desire to be educational partners. Knowing that there are benefits associated with participation, reciprocity, and a sense of belonging, may contribute to online participation among adult learners (Diep et al., 2016). The online environment offers the adult learner the ability to work as collaborative partners in the learning process due to the nature of the online discussions and sharing of assignments (Rudestam \& Schoenholtz-Read, 2002). Having access to the discussions and assignments 24/7 allows the adult learners to contribute ideas dependent on their own schedules and when it is convenient for them.

Adult learning theory differs markedly from pedagogy (Knowles, Holton, \& Swanson, 1998). Although online instructors direct learning as offered in the pedagogy model, the adult learning theory places learners in positions to direct learning as well. Allowing for direct learning refers to devising a learning atmosphere where learners address topical 
issues pertaining to their experiences and workplace, as well as providing an opportunity for them to play a role in open course discussions.

Adult learning theory finds its roots in andragogy (Knowles et al., 1998). Andragogy provides six principles for adult learning theory including: learners' need to know why they are learning; learners use self-directed learning; learners learn based on experiences; learners have a readiness to learn; learners have an orientation to learn; and learners have a high motivation to learn (Ota et al., 2006). As suggested by Knowles et al. (1998) and Cherne (2002), adult learners can direct their own learning, have life experiences that can be used in the classroom, and look to apply the knowledge learned to their current world, which seems to connect to the six principles of adult learning theory. Soundly designed online courses lend to this type of learning with materials delivered in an asynchronous fashion, permitting learners the opportunity to complete assignments relating their experiences to theory and doing so according to their schedules.

\section{CONSTRUCTIVIST APPROACH}

The constructivist approach to learning is based on the idea that learners create knowledge through interactions with others (Bruner, 1996). The constructivist approach is an oppositional stance to the traditional approach where the student takes a passive role in learning (Markel, 1999). The constructivist theory varies from traditional theories in that it shifts from memorization to implementation. With the constructivist approach to learning, the instructor takes on the role as facilitator, directing discussions and providing general parameters for the course. As Carr-Chellman and Duchastel (2000) explained the: traditional delivery of instruction receives much less attention in online courses than in the traditional context of higher education...we are moving, here, toward a more student-centered and activity-based learning environment design. (para. 8)

Lovejoy (2002) supports this notion by indicating that adult learners have both individual and group roles in the online environment. Student-centered learning and the constructivist approach take precedent in the online learning environment. Online classrooms often compliment studentcentered learning in that they provide a "medium in which the self is readily constructed in diverse ways and in which students readily form different opinions and interpretations regarding the same reading material and commentaries" (Rudestam \& Schoenholtz-Read, 2002, p. 16). In addition, the constructivist approach fits well with the paradigm of online learning, whereby knowledge is something that is actively constructed and not just something that can be found in lectures, books, and traditional aspects of higher education (Rudestam \& Schoenholtz-Read, 2002, p. 18). Formerly prescribed methods of instruction such as formal lectures and memorization of materials, while used sparingly in the online classroom, are merely a spring board for the conversations and assignments, such as Socratic questions, in-depth discussions, and case analyses that follow and serve to direct the course and build student learning.

From the perspective of collaboration and team work in an online setting, the constructivist theory promotes more dialogue amongst students as each student is perpetually asked to discuss his/her understanding and then compare that understanding to his/her peers. This differs from traditional learning environments where students are often asked to merely regurgitate 
information. Furthermore, team discussions are much more likely to spark ideas and allow students to learn new concepts and theories in relation to their experiences as well as the experiences of their peers, thus continuing to facilitate the constructivist view of learning. Collaboration within a constructivist model supports a learning community where there is ongoing dialogue for the adult learner to enhance individual learning and the sharing of knowledge. Nonaka and Takeuchi (1995) explain that the "value of any one person's contribution is determined less by his or her location in the organizational hierarchy than by the importance of the information she or he provides to the entire knowledge-creating system" (p. 151). In an online classroom, embracing the constructivist approach, this perspective is pivotal to adult learning because the student is working within a system to build knowledge and understanding of the concepts. In addition, an online classroom creates situations where students can take what they learn back to their respective work organizations. There is a strong aspect of realworld application throughout these courses, which has a direct impact on society.

In reality, a good online class strives to create an environment of collaboration by not only requiring weekly discussion questions but also by having students share assignments, reflect on the work of their peers, and their own experiences. Much of this is done through the incorporation of teamwork. Teamwork is a key element to adult education because "much of the work in larger organizations is now done in work groups or teams" (Bolman \& Deal, 1997, p. 81). Creating teams to work towards the accomplishment of a common goal is important "because they provide a shared context where individuals can interact with each other and engage in the constant dialogue on which effective reflection depends" (Nonaka, 1998, p. 44). Thus, online learning helps to better prepare the adult learner for today's work world.

\section{FLEXIBILITY AND AdULt EdUCATION}

Generally, adults looking for educational opportunities tend to be busy individuals with their careers, families, and volunteer activities (Rudestam \& Schoenholtz-Read, 2002; White \& Weight, 2000). Because of adults' busy lives, the postmodern business world has presented a need for many working adults to expand their education. As Hannay and Newvine (2006) suggest, adults may choose non-traditional models because they are associated with programs that "provide access to higher education for students who cannot attend traditional courses due to employment, marital status, family responsibilities, distance, and expenses incurred with traditional education" (para. 1). This diversity ultimately contributes to a rich learning environment. Ko and Rossen (2001) added that a benefit of online education is that "it opens the student to more information from all involved in the class. When students are limited to the information the instructor provides, it reduces the courses breadth and scope" (p. 105). The lack of social and demographic boundaries in online education make the learning not only more flexible, but multi-dimensional.

\section{ADULTS FROM VARIOUS LOCATIONS}

Online education provides an opportunity for learners from various regions throughout the world to come together to obtain an education. The ability to interact with peers has been identified as an important component in the online learning experience (Lucey, 2018). The online, asynchronous mode of learning means that a person living in a remote North American town, a person in Alaska, and a person on a military base in 
Bosnia can all obtain the same education from the same program. This opportunity not only means that education is available to more people, but that classes can now provide individuals with the opportunity to experience a diversity of thought. As many organizations move towards global operations (Shafritz \& Ott, 1996), the online form of education serves yet another purpose by helping the adult to learn to work with diverse individuals. Such opportunities are rarely provided by traditional classroom learning experiences.

\section{Conclusions}

Online, asynchronous education lends itself to adult learning in that the teacher can facilitate learning and offer collaborative, flexible, diverse opportunities for the students. The online classroom also allows for more indepth discussions, which students can direct with the guidance of their online facilitator.
Being able to go to class anytime and anywhere presents adult learners with the advantage of being able to hold a job, maintain a family, and enjoy other activities all while gaining a valuable education. Finally, the online mode of learning serves to capitalize on collaboration and team work. This is an important aspect for working adults today in that many organizations are now moving towards teambased projects and programs in the workplace. Online education provides a viable alternative to the adult learner searching to further his/her knowledge base and educational credentials.

Although online education is continually changing and developing, it may be a viable option for many adult learners. More research needs to be done in this field in order to fully understand the impact that online education can have on an adult population. 


\section{REFERENCES}

Bolman, L., \& Deal, T. (1997). Reframing organizations: Artistry, choice, and leadership ( ${ }^{\text {nd }}$ ed.). San Francisco: Jossey-Bass Publishers.

DePaepe, L., Zhu, C., and DePryck, K. (July 2018). Drop-out, retention, satisfaction, and attainment of online learners of Dutch in adult education. International Journal on E-Learning, 17, 303-323.

Diep, N. A., Cocquyt, C., Chang, Z., \& Vanwing, T. (2016). Predicting adult learners' online participation: Effects of altruism, performance expectancy, and social capital. Computers and Education, 84-101.

Hannay, M., \& Newvine, T. (2006). Perceptions of distance learning: A comparison of online and traditional learning. Journal of Online Learning and Teaching, 2, 1-11.

Harvard business review on knowledge management. (1998). Boston, MA: President and Fellows of Harvard College.

Hiltz, S. R. (1997). Impacts of college-level courses via asynchronous learning networks: Some preliminary results. Journal of Asynchronous Learning Networks, 1, 1-19.

Knowles, M., Holton, E., \& Swanson, R. (1998). The adult learner (5th ed.). Texas: Random House.

Ko, S., \& Rossen, S. (2001). Teaching online: A practical guide. Boston: Houghton Mifflin.

Lucey, K. (2018). The effect of motivation on student persistence in online higher education: A phenomenological study of how adult learners experience motivation in a web-based distance learning environment (Doctoral dissertation). Available from Proquest Dissertations Publishing (10750789).

Luscinski, A. (2017). Best practices in adult online learning (Doctoral dissertation). Available from ProQuest Dissertation Publishing (10608529).

Mathis, R., \& Jackson, J. (2003). Human resource management. (10 th ed.). Ohio: Thomson South-Western.

Ota, C., DiCarlo, C. F., Burts, D. C., Laird, R., \& Gioe, C. (2006). Training and the needs of adult learners. Journal of Extension.

Rudestam, K., \& Schoenholtz-Read, J. (2002). Handbook of online learning: Innovations in higher education and corporate training. London: Sage Publication.

Shafritz, J., \& Ott, S. (1996). Classis of organization theory ( $4^{\text {th }}$ ed.). New York: Harcourt Brace College Publishers

White, K., \& Weight, B. (2000). The online teaching guide: A handbook for attitudes, strategies, and techniques for the virtual classroom. Boston: Allyn \& Bacon,

Wright, L. (2015). Identifying successful online adult learners (Doctoral dissertation). Available from ProQuest Dissertation Publishing (3721680). 